\title{
Bacterial Blight and Dieback of Eucalyptus Species, Hybrids, and Clones in South Africa
}

T. A. Coutinho and O. Preisig, Department of Microbiology and Plant Pathology, Forestry and Agricultural Biotechnology Institute (FABI), University of Pretoria, Pretoria 0002, South Africa; J. Mergaert and M. C. Cnockaert, Laboratorium voor Microbiologie, Universiteit Gent, K. L. Ledeganckstraat 35, B-9000 Gent, Belgium; K.-H. Riedel, School for Environmental Sciences and Development: Microbiology, Potchefstroom University for Christian Higher Education, Private Bag X6001, Potchefstroom 2520, South Africa; J. Swings, Laboratorium voor Microbiologie and BCCM/LMG Culture Collection, Universiteit Gent, K. L. Ledegranckstraat 35, B-9000 Gent, Belgium; and M. J. Wingfield, Department of Microbiology and Plant Pathology, Forestry and Agricultural Biotechnology Institute (FABI), University of Pretoria, Pretoria 0002, South Africa

\begin{abstract}
Coutinho, T. A., Preisig, O., Mergaert, J., Cnockaert, M. C., Riedel, K.-H., Swings, J., and Wingfield, M. J. 2002. Bacterial blight and dieback of Eucalyptus species, hybrids, and clones in South Africa. Plant Dis. 86:20-25.

During 1998, a new disease appeared on trees representing a Eucalyptus grandis $\times$ E. nitens (GN) hybrid in a nursery in KwaZulu/Natal. The disease has subsequently spread to other Eucalyptus species, hybrids, and clones in nurseries and plantations throughout South Africa. Typical symptoms of the disease include dieback of young shoots and leaf blight. This ultimately leads to stunting of trees. The objective of this study was to isolate and identify the causal agent of the disease. A bacterium was consistently isolated from infected tissue. Pathogenicity tests were undertaken with a range of bacterial strains. Four pathogenic strains were selected from different geographical regions and Eucalyptus hosts for further study. The bacterium causing Eucalyptus leaf and shoot blight is gram negative and rod-shaped, varying in size from 0.5 to 0.75 $\mu \mathrm{m}$ wide and 1.0 to $2.0 \mu \mathrm{m}$ long. Colonies of this bacterium have a yellow pigment. The results from the Biolog tests identified the bacterium as Pantoea agglomerans with a similarity index of 0.315 . The $16 \mathrm{~S}$ rDNA sequences of the purported Pantoea sp. were compared with those of other related Enterobacteriaceae from GenBank/EMBL. Phylogenetic analysis using PAUP revealed that the isolates group together with $P$. agglomerans, $P$. ananatis, and $P$. stewartii subsp. stewartii. The fatty acid profiles and phenotypic characteristics of the new pathogen are similar to $P$. ananatis, and $\% \mathrm{G}+\mathrm{C}$ is within the range of this species. DNA:DNA hybridization between the four strains and the type strain of $P$. ananatis conclusively showed that the bacterium causing blight and dieback of Eucalyptus in South Africa belongs to this species. This is the first report in which P. ananatis has been found as a causal agent of a disease on Eucalyptus.
\end{abstract}

Additional keywords: Erwinia ananas, Erwinia uredovora

In South Africa, Eucalyptus species, hybrids, and clones are grown commercially and account for more than $50 \%$ of all newly afforested areas (1). This hardwood tree is used for the production of solid timber products and is also the basis of an internationally important pulp and paper industry. A number of fungal diseases cause severe damage to eucalypts in South Africa, notably Cryphonectria canker (4), Coniothyrium canker (26), Botryosphaeria canker $(19,20)$, and Mycosphaerella leaf blotch (6). Thus far, only two bacterial diseases have been reported on this host, namely bacterial wilt caused by Ralstonia

Corresponding author: T. A. Coutinho

E-mail: Teresa.Coutinho@fabi.up.ac.za

Accepted for publication 19 September 2001.

Publication no. D-2001-1105-01R

(C) 2002 The American Phytopathological Society solanacearum (7) and bacterial dieback caused by Xanthomonas eucalypti (22). Bacterial wilt has recently been reported for the first time on Eucalyptus in South Africa (5), while in Australia bacterial dieback has been found only on Eucalyptus citriodora (22).

In 1998, a severe disease appeared in a single nursery in KwaZulu/Natal, South Africa, on ramets of an $E$. grandis $\times E$. nitens (GN) hybrid clone. The disease subsequently spread to other nurseries and commercial plantations and to a number of different Eucalyptus species, hybrids, and clones. Typical symptoms of bacterial blight (Fig. 1) include tip dieback and leaf spots on young leaves. The leaf spots are initially water-soaked and often coalesce to form larger lesions. The pathogen appears to spread from the leaf petiole into the main leaf vein and from there to the adjacent tissue. Thus, lesions on the leaf are often concentrated along the main veins. Leaf petioles become necrotic, which re- sults in premature abscission of the leaves. Trees assume a scorched appearance in the advanced stages of the disease and after repeated infections become stunted. Due to the resultant formation of many new growing tips and epicormic shoots, the trees have a bushy appearance. Highly susceptible species, hybrids, and clones exhibit a combination of dieback and blight symptoms, while those more tolerant show only leaf spot symptoms. A bacterium was consistently isolated from symptomatic tissue and tentatively identified as an Erwinia sp. based on morphology, motility, colony color, fermentative utilization of glucose, and results from catalase and oxidase tests.

The disease on Eucalyptus is more prevalent in areas of South Africa where the temperatures are relatively low (between 20 and $25^{\circ} \mathrm{C}$ ) and the relative humidity high. The means of entry of this pathogen into its host has yet to be established. However, in nurseries where vegetative propagation is practiced, the bacterium enters the cut surfaces of cuttings and reduces their ability to root by nearly $100 \%$.

Eucalyptus spp. belong to the family Myrtaceae. The only member of this family that is reported to be affected by an Erwinia sp. is guava (Psidium guajava). In 1987, a previously undescribed bacterial disease caused severe losses of guava trees in Brazil (16). The pathogen attacked branches and twigs, causing severe dieback and ultimately death of trees. The pathogen was identified as Erwinia psidii sp. nov. Pathogenicity tests were undertaken with different members of the Myrtaceae. E. citriodora and E. saligna were included but were found not be hosts of this pathogen.

The objective of this study was to identify the causal agent of bacterial blight and dieback affecting important Eucalyptus species, hybrids, and clones in South Africa. Pathogenicity tests were undertaken, and the causal agent was characterized both phenotypically and genotypically using a variety of techniques.

\section{MATERIALS AND METHODS}

Isolation procedures. Plant material showing typical symptoms of the disease 
was collected from nurseries and commercial plantations of Eucalyptus in South Africa. Leaves with distinct water-soaked lesions, as well as wilted shoots, were surface-sterilized in a $10 \%$ solution of commercial bleach $(5.25 \%$ sodium hypochlorite), washed with sterile distilled water, and then placed in a sterile mortar containing $1 \mathrm{ml}$ of sterile distilled water. The leaves were crushed with a sterile pestle, and the resulting suspension was streaked onto nutrient agar (Biolog, Hayward, CA). The cultures were incubated at $30^{\circ} \mathrm{C}$ for 3 days.

Pathogenicity tests. Pathogenicity tests were conducted on an E. grandis $\times E$. nit- ens (GN) clone found to be highly susceptible to the bacterial blight pathogen in nurseries and plantations. Twenty 3-monthold plants were inoculated with each bacterial strain in two separate experiments. Two inoculation methods were used: a fine needle was dipped into a bacterial suspension $\left(2 \times 10^{6} \mathrm{CFU} / \mathrm{ml}\right)$ and then gently inserted into the surface of young leaves (four wounds were made per leaf) and into the petioles of young leaves. Control plants were inoculated with sterile water. Plants were incubated in a controlled environment chamber (Controlled Environments Ltd., Winnipeg, Manitoba, Canada) at temperatures between 20 and $23^{\circ} \mathrm{C}$ and relative humidity between 80 and $90 \%$. The plants were inspected daily. Once symptoms were expressed, bacteria were reisolated from infected leaves using the technique described previously. The reisolated strains were compared with the inoculated strains using selected phenotypic tests (morphology, Gram stain, colony morphology, Hugh-Leifson, oxidase, and catalase tests).

Nutritional and physiological tests. Once pure cultures of the bacterial strains were obtained, characteristics such as cell morphology, Gram stain, colony morphology, and flagellar arrangement were determined. The Hugh-Leifson oxidation/ fermentation, oxidase, and catalase tests
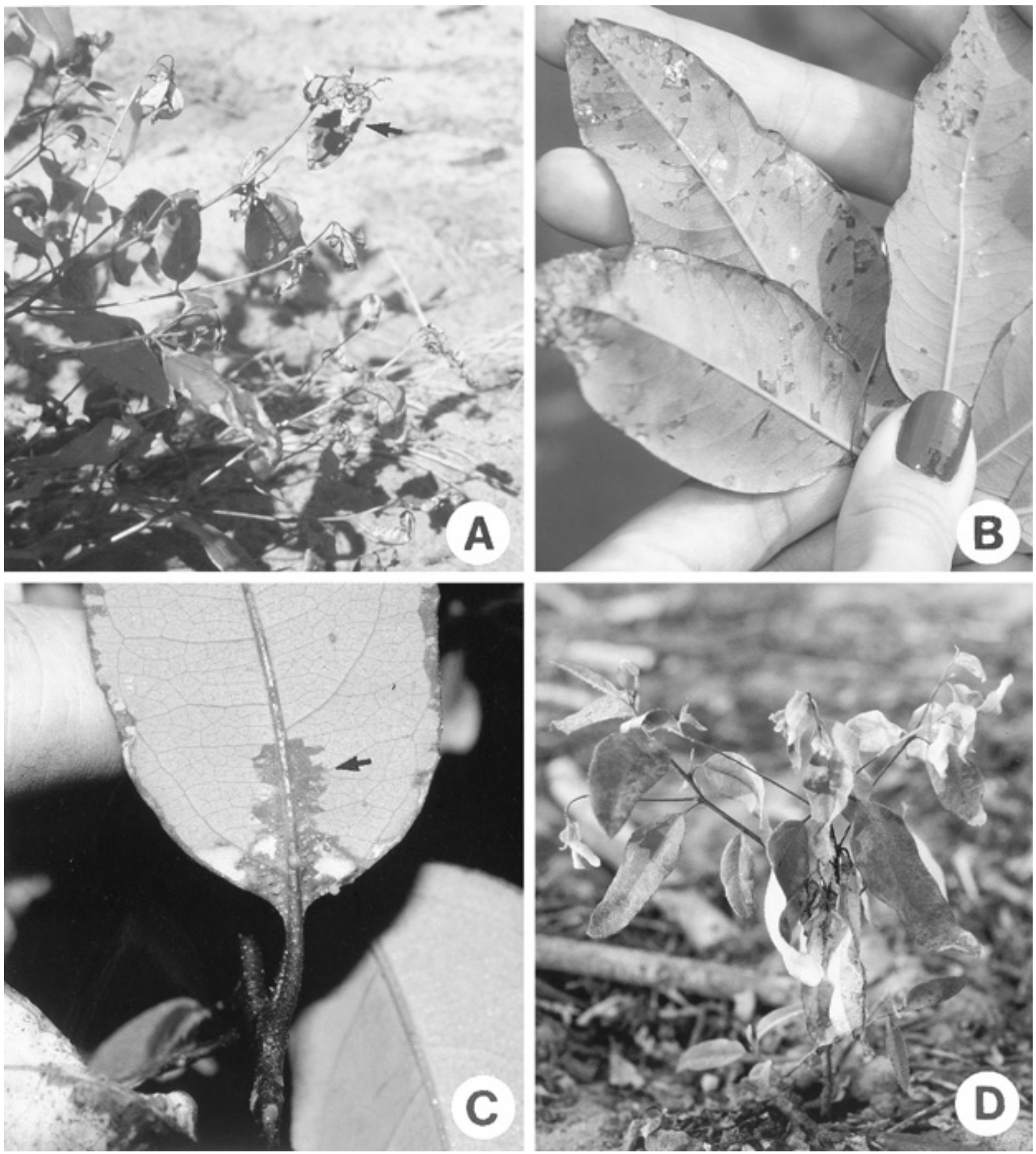

Fig. 1. Symptoms associated with bacterial blight and dieback of Eucalyptus. A, Typical dieback symptoms (arrow). B, Water-soaked spots on leaves. C, Lesions coalescing along the main vein of the leaf (arrow). D, Scorched leaves and shoots. 
also were conducted. The bacterial strains were identified using Biolog's Gram negative GN Microplate technique, together with Biolog's MicroLog version 4.0 software (Biolog).

Tests forming part of the API $20 \mathrm{E}$ and API 50 CHE systems (BioMérieux, La Balme les Grottes, Montalieu Vercieu, France) were performed on the four strains from Eucalyptus and the type strain of Pantoea ananatis, LMG $2665^{\mathrm{T}}$, using the procedure described by Mergaert et al. (14). Acid production from carbohydrates and esculin hydrolysis was recorded after $48 \mathrm{~h}$ using the API $50 \mathrm{CHE}$ tests. Gelatin liquefaction, indole acetoin, and hydrogen sulfide production, arginine dihydrolase, lysine, and ornithine decarboxylases, tryptophan deaminase, B-D-galactosidase, urease, and citrate utilization were recorded after $24 \mathrm{~h}$ using the API 20E tests. Profiles were identified using the APILAB V4.0 identification program (BioMérieux).

Fatty acid analysis. The strains from Eucalyptus and LMG $2665^{\mathrm{T}}$ were characterized by the profiles of fatty acid methyl ester separated by gas-liquid chromatography. The profiles were compared with those of known species in the Microbial Identification System (MIS) database, TSBA version 4.0 (MICROBIAL ID Inc., Newark, DE).

16S rRNA gene amplification and sequencing. A section of the 16S rRNA gene of the four strains was amplified using the universal eubacterial primer pairs, fD1 (5'AGA GTT TGA TCC TGG CTC AG-3') and rD1 (5'-AAG GAG GTG ATC CAG
CCG CA-3') (25). The purified polymerase chain reaction (PCR) products were cloned and then sequenced with the primers fD1 and $\mathrm{rD1}$ as well as with the internal primers OT1 (5'-GAA GAA GGC CTT CGG GTT G-3') and OT2 (5'-CAC GAC ACG AGC TGA CGA C-3') (25) using the Big Dye terminator cycle sequencing kit (Applied Biosystems, Foster City, CA). Sequences were analyzed using an ABI Prism 377 DNA sequencer and edited with the program Sequence Navigator (Applied Biosystems). The GenBank/EMBL databases were used for homology searches using the BLAST program (National Center for Biotechnology Information, U.S. National Institutes of Health, Bethesda, MD). A selection of $16 \mathrm{~S}$ rDNA sequences obtained from a BLAST search were aligned with the partial sequences of the four strains using CLUSTALW (21). The alignment was trimmed of the overhangs before parsimony analysis. Heuristic searches with maximum parsimony used stepwise (simple) addition and treebisection-reconnection to produce a phylogenetic tree (PAUP 4.0b3, D. L. Swofford, Illinois Natural History Survey, Champaign). Bootstrap values were obtained from the same data matrix.

DNA base composition determination. The strains from Eucalyptus and type strain LMG $2665^{\mathrm{T}}$ were grown on nutrient agar (Oxoid, Basingstoke, Hampshire, England) at $28^{\circ} \mathrm{C}$. DNA was extracted from these isolates using the method described by Pitcher et al. (17). DNA base composition was determined using the

Table 1. Bacterial strains from Eucalyptus characterized in this study

\begin{tabular}{lll}
\hline Strain Number & Origin & Host \\
\hline LMG 20103 & Piet Retief, Mpumalanga & E. grandis $\times$ E. nitens hybrid A \\
LMG 20104 & Harding, KwaZulu/Natal & E. grandis Clone A \\
LMG 20105 & Pietermaritzburg, KwaZulu/Natal & E. grandis $\times$ E. nitens hybrid B \\
LMG 20106 & Tzaneen, Northern Province & E. grandis Clone B \\
\hline
\end{tabular}

Table 2. Fatty acid compositions of bacterial strains from Eucalyptus and Pantoea ananatis LMG $2665^{\mathrm{T}}$

\begin{tabular}{lcc}
\hline & \multicolumn{2}{c}{ Percentage of total } \\
\cline { 2 - 3 } Feature & $\begin{array}{c}\text { Bacterial strains } \\
\text { from Eucalyptus } \\
\text { (range for four isolates) }\end{array}$ & $\begin{array}{c}\text { Pantoea ananatis } \\
\text { LMG 2665 }\end{array}$ \\
\hline (average of five replicates)
\end{tabular}

$\mathrm{z}$ Also found in some or all isolates in trace amounts ( $\leq 1 \%$ of total): 10:0 3OH, 13:0, 12:0 2OH, 12:0 3OH, unknown 13.957, unknown 14.502, 15:0 anteiso, 16:0 N alcohol, 17:1 $\omega 8 \mathrm{c}, 16: 03 \mathrm{OH}, 18: 0$, 19:0 cyclo, summed feature 1 . Summed feature 1 comprises any combination of 15:1 iso H, 15:1 iso I, and 13:0 3OH. Summed feature 2 comprises any combination of 12:0 aldehyde, unknown $10.928,16: 1$ iso I, and 14:0 3OH. Summed feature 3 comprises 15:0 iso $2 \mathrm{OH}, 16: 1 \omega 7 \mathrm{c}$, or both. high-pressure liquid chromatography (HPLC) method. DNA was enzymatically degraded into nucleotides using the method described by Mesbach et al. (15). The obtained nucleotide mixture was then separated by HPLC using a Waters Symmetry Shield $\mathrm{C} 8$ column at $37^{\circ} \mathrm{C}$. The solvent used was $0.02 \mathrm{M} \mathrm{NH}_{4} \mathrm{H}_{2} \mathrm{PO}_{4}(\mathrm{pH}=4.0)$ with $1.5 \%$ acetonitrile. Nonmethylated lambda phage DNA (Sigma Chemical Co. St. Louis, MO) was used as the calibration reference.

DNA-DNA hybridizations. DNA-DNA hybridizations were performed with photobiotin-labeled probes in microplate wells as described by Ezaki et al. (8). A HTS7000 BioAssay Reader (Perkin-Elmer Cetus, Norwalk, CT) was used for the fluorescence measurements. The hybridization temperature was $40^{\circ} \mathrm{C}$. Reciprocal experiments were performed for every pair of strains, and the means from reciprocal tests are presented.

\section{RESULTS}

Isolation procedures. Bacteria were consistently isolated from infected leaves. No bacteria were isolated from healthy tissue. For characterization and pathogenicity tests, four strains from different Eucalyptus hosts and geographic regions were used (Table 1). Strains LMG 20103, LMG 20104, LMG 20105, and LMG 20106 were deposited in the BCCM/LMG Culture Collection (Universiteit Gent, Belgium).

Pathogenicity tests. Water-soaked lesions developed on leaves of all plants inoculated with all four strains 3 days after inoculation. After 10 days, the lesions were necrotic and in some cases had coalesced. After 14 days, large necrotic lesions had developed on the leaves, and there appeared to be no progression of symptoms from these lesions into the main vein and petioles of the host plant. When leaf petioles were inoculated with the pathogen, tissue adjacent to the main vein became water-soaked after 6 days, and after 14 days the leaves wilted, became necrotic, and abscised from the plant. A Pantoea sp. was reisolated from lesions on the leaves and from main veins using the method described previously. Control plants showed no symptoms. The Pantoea sp. isolated from these inoculated plants was shown to be identical, based on phenotypic characteristics, to the original strains used in these pathogenicity tests.

Nutritional and physiological tests. The strains isolated from Eucalyptus species, hybrids, and clones showing typical symptoms of bacterial blight and dieback were Gram negative, rod-shaped, 0.5 to $0.75 \mu \mathrm{m}$ in width and 1.0 to $2.0 \mu \mathrm{m}$ in length with a peritrichous flagella arrangement. All strains were yellow pigmented. The strains fermentatively utilized glucose and were oxidase negative and catalase positive. Computer analysis of the 
data using the Biolog Gram negative microplate system showed that the strains belong to the Enterobacteriaceae. Although the Biolog system gave no exact identification, as reflected by the low percent similarity, the metabolic profile of the bacterial strains most closely resembled the database profile of Pantoea agglomerans, with a similarity index of 0.315 .

Strains LMG 20103, LMG 20104, LMG 20105, and LMG 20106 and Pantoea ananatis strain LMG $2665^{\mathrm{T}}$ were positive for acid production from glycerol, Larabinose, ribose, D-xylose, D-galactose, Dglucose, D-fructose, D-mannose, L-rhamnose, meso-inositol, mannitol, sorbitol, $\mathrm{N}$ acetylglucosamine, arbutine, salicine, cellobiose, maltose, lactose, melibiose, saccharose, trehalose, D-raffinose, D-arabitol, esculine hydrolysis, $\beta$-galactosidase, citrate utilization, indole production from tryptophan, and acetoin production. The strains were negative for acid production from meso-erythritol, D-arabinose, L-xylose, adonitol, B-methylxyloside, L-sorbose, dulcitol, •-methyl-D-glucoside, inuline, melezitose, starch, glycogen, meso-xylitol, D-turanose, D-lyxose, D-tagatose, D- and Lfucose, L-arabitol, gluconate, 2-ketogluconate, 5-keto-gluconate, arginine dihydrolase, lysine decarboxylase, ornithine decarboxylase, hydrogen sulfide production, and tryptophan deaminase. Different reactions, positive or negative, were obtained for urease and $\alpha$-methyl-Dmannoside, amygdalin, and D-gentiobiose.

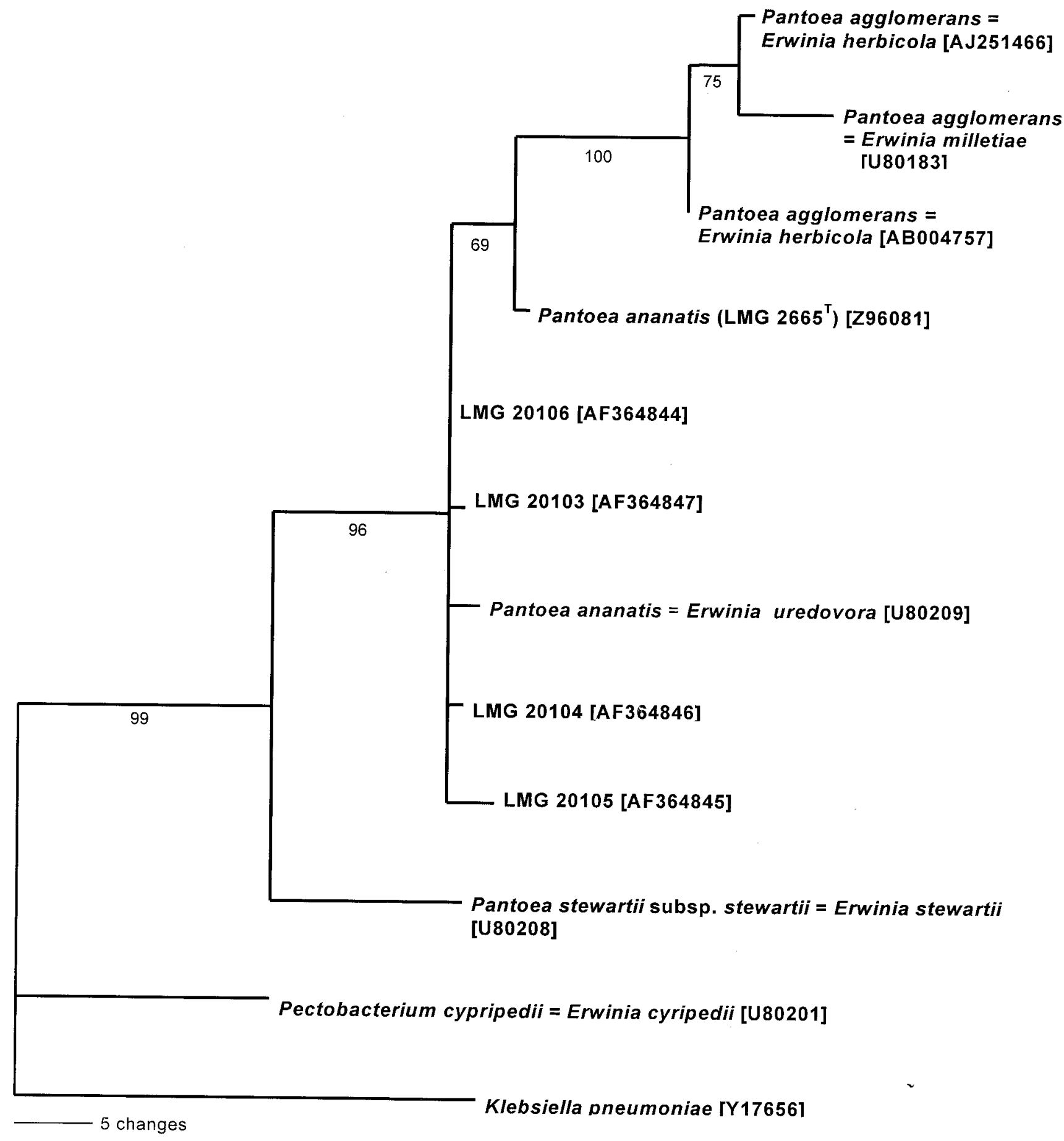

Fig. 2. One of seven most parsimonious trees of 114 steps based on selected partial $16 \mathrm{~S}$ rDNA sequences from Pantoea species, including the four strains from Eucalyptus. The sequence of Klebsiella pneumoniae was used as an outgroup taxon. Bootstrap values are marked below the branches. Accession numbers of the sequences obtained from the GenBank/EMBL databases have been placed in brackets. 
Unlike Pantoea ananatis LMG $2665^{\mathrm{T}}$, the strains from Eucalyptus liquefied gelatin. Urease was reported to be negative for all 18 strains of $P$. ananatis studied by Mergaert et al. (13), while gelatinase and acid production from $\alpha$-methyl-D-mannoside, amygdalin, and D-gentiobiose differed among $P$. ananatis strains. The profiles of the strains from Eucalyptus were not recognized unambiguously by the API 20E recognition program.

Fatty acid analysis. The fatty acid compositions of the Eucalyptus strains were very similar to that of $P$. ananatis LMG $2665^{\mathrm{T}}$ (Table 2) and to those of $18 P$. ananatis strains as reported by Mergaert et al. (13). The MIS identification program identified the Eucalyptus strains as Cedecea davisae (maximum score 0.583), and $P$. ananatis was the second most similar (maximum score 0.474).

16S rDNA sequence analysis. Partial $16 \mathrm{~S}$ rDNA sequences of the four suspected Erwinia spp. were obtained and deposited into the GenBank database with accession numbers AF364844 (LMG 20106), AF364845 (LMG 20105), AF364846 (LMG 20104), and AF364847 (LMG 20103). With the exception of a few nucleotide differences, the four sequences were identical. A BLAST search with the $1.5-\mathrm{kb} 16 \mathrm{~S}$ rDNA sequences of the four strains supported the Biolog results that the isolates belong to a species of Pantoea. The highest homologies were to the $16 \mathrm{~S}$ rDNA of E. uredovora (accession number U80209) and of $P$. ananatis LMG $2665^{\mathrm{T}}$ (accession number Z96081) with identities of 99.7 and $99.0 \%$, respectively. Seven most parsimonious trees were produced from the analysis of the aligned sequences of the 1.3-kb 16S rDNA sequences generated in this study and of other Enterobacteriaceae (Fig. 2). Of the 1,295 characters used, 46 of the variable characters were parsimony uninformative and 44 parsimony informative. The total tree length was 114 steps, consistency index was 0.877 , and the retention index was 0.825 . The trees show clearly that the sequences for the isolates in this study group into a cluster with $P$. ananatis (syn. Erwinia uredovora).

DNA base composition determination and DNA-DNA hybridizations. The DNA base ratios for the bacterial strains from Eucalyptus were 52.8 to $53.9 \mathrm{~mol} \% \mathrm{G}+\mathrm{C}$ and for $P$. ananatis LMG $2665^{\mathrm{T}}$ were 53.3 mol $\% \mathrm{G}+\mathrm{C}$. The DNA-DNA binding ratios among the bacterial strains from Eucalyptus and $P$. ananatis LMG $2665^{\mathrm{T}}$ were between 94 and 103\%, with an average SD of $12 \%$, which is slightly above the SD of $7 \%$ mentioned by Goris et al. (11).

\section{DISCUSSION}

In this study we report, for the first time, on the occurrence of bacterial blight and dieback initiated by $P$. ananatis on Eucalyptus in South Africa. Koch's postulates were confirmed using four strains, and these were subjected to further taxonomic investigation. Phenotypic characterization of the strains supported our preliminary results that the causal agent of the disease is a Pantoea sp. The genus Pantoea was established in 1989 and includes plantpathogenic species formerly classified as Erwinia herbicola, E. milletiae (9), E. ananas, E. uredovora, and E. stewartii (13). This is the first report of a Pantoea sp. infecting Eucalyptus. It also records a serious new disease problem affecting one of the most widely planted forest trees in South Africa and elsewhere in the world.

The genotypic characterization of the four strains from Eucalyptus confirmed that the causal agent is $P$. ananatis (synonyms, Erwinia ananas and E. uredovora, 13). Hauben et al. (12) showed, using $16 \mathrm{~S}$ rDNA sequences of 29 plant-associated strains, representing Erwinia, Pantoea, and other Enterobacteriaceae, that three phylogenetic groups exist within Pantoea. Pantoea spp. group in a monophyletic unit (Cluster IV) that is closely related to the true Erwinia species. The values obtained for the DNA base ratios of the four strains were similar to the 53.1 to $55.2 \%$ reported for 10 authentic strains of $P$. ananatis (13). The DNA binding ratios between the isolates from Eucalyptus and $P$. ananatis LMG $2665^{\mathrm{T}}$ were higher than $94 \%$. The microplate method used in this study has been shown to be well correlated to the initial renaturation method used by Mergaert et al. (13), who found $76 \%$ as the lowest binding value among strains classified as $P$. ananatis. Morphological, nutritional, and physiological characteristics and fatty acid compositions were very similar to those of $P$. ananatis LMG $2665^{\mathrm{T}}$ and those reported for 18 strains of this species (13). We thus conclude that the bacterium associated with Eucalyptus leaf blight and dieback belongs to this species.

$P$. ananatis was first reported as a pathogen of pineapple fruitlets, causing brown rot (18). However, there has been no supplementary evidence of this disease on this host since the original report in 1928 . Sudangrass, cantaloupe fruit, sugarcane, onions, and honeydew melons have also been reported as hosts of this pathogen $(2,3,8,10,24)$. In a recent study by van Zyl (23), two Pantoea spp. were found to exist in a synergistic relationship with a fungal pathogen of Eucalyptus, Coniothyrium zuluense, which causes a serious canker disease of this host. Using 16S rRNA gene sequence comparisons, one of the Pantoea spp. was identified as $P$. ananatis. The fact that the bacterium found to be responsible for bacterial blight and dieback is the same as that involved in Coniothyrium canker is intriguing and deserves further investigation.

Bacterial blight and dieback has become a serious problem in nurseries and young plantations throughout South Africa. Not only is the bacterium infecting cuttings but also ramets in the nursery. This seriously hinders the ability of forestry companies to produce vegetative material for rooting. $P$. ananatis has the ability to infect a number of Eucalyptus clones, hybrids, and species, including E. grandis, E. saligna, E. dunnii, E. nitens, E. smithii, E. grandis $\times E$. camadulensis (GC), and E. grandis $\times E$. urophylla (GU). This is of considerable concern, as these represent some of the most crucial planting stock on which a major forestry industry is based. There are, however, significant differences in susceptibility among $E$. grandis clones, and this provides an excellent opportunity for the selection of tolerant material. Development of management strategies to reduce the impact of this disease is now a priority. A rapid screening technique to detect this bacterium is needed, and commercially important clones should be tested to determine their level of tolerance to this disease.

\section{ACKNOWLEDGMENTS}

We thank members of the Tree Pathology Cooperative Programme (TPCP), the National Research Foundation (NRF), and the THRIP initiative of the Department of Trade and Industry, South Africa, for their financial support. We also thank Shalati Shiburi, Carina Esterhuizen, and Marinda Oosthuizen for technical support, Fanus Venter for his critical review of this manuscript, and Jolanda Roux for the photographs.

\section{LITERATURE CITED}

1. Anonymous. 1996. Extract of South African Forestry Facts of the year 1993/1994. Department of Water Affairs and Forestry and Forest Owners Association.

2. Azad, H. R., Holmes, G. J., and Cooksey, D. A. 2000. A new leaf blotch disease of Sudangrass caused by Pantoea ananas and Pantoea stewartii. Plant Dis. 84:973-979.

3. Bruton, B. D., Wells, J. M., Lester, G. E., and Patterson, C. L. 1991. Pathogenicity and characterization of Erwinia ananas causing a postharvest disease of cantaloup fruit. Plant Dis. 75:180-183.

4. Conradie, E., Swart, W. J., and Wingfield, M. J. 1990. Cryphonectria canker of Eucalyptus, an important disease in plantation forestry in South Africa. S. Afr. For. J. 152:43-49.

5. Coutinho, T. A., Roux, J., Riedel, K.-H., Terblance, J., and Wingfield, M. J. 2000. First report of bacterial wilt caused by Ralstonia solanacearum on eucalypts in South Africa. For. Pathol. 30:205-210.

6. Crous, P. W., and Wingfield, M. J. 1996 Species of Mycosphaerella and their anamorphs associated with leaf blotch disease of Eucalyptus in South Africa. Mycologia 88:441-458.

7. Dianese, J. C., Dristig, M. C. G., and Cruz, A P. 1990. Susceptibility to wilt associated with Pseudomonas solanacearum among six species of Eucalyptus growing in equatorial Brazil. Australas. Plant Pathol. 19:71-76.

8. Ezaki, T., Hashimoto, Y., and Yabuuchi, E. 1989. Fluorometric deoxyribonucleic aciddeoxyribunucleic acid hybridisation in microdilution wells as an alternative to membrane filter hybridisation in which radioisotopes are used to determine genetic relatedness among bacterial strains. Int. J. Syst. Bacteriol. 39:224-229.

9. Gavini, F., Mergaert, J., Beji, A., Mielcarek, C., Izard, D., Kersters, K., and De Ley, J. 
1989. Transfer of Enterobacter agglomerans (Beijerinck 1988) Ewing and Fife 1972 to Pantoea gen. nov. as Pantoea agglomerans comb. nov. and description of Pantoea dispersa sp. nov. Int. J. Syst. Bacteriol. 39:337-345.

10. Gitaitis, R. D., and Gay, J. D. 1997. First report of a leaf blight, seed stalk rot, and bulb decay of onion by Pantoea ananas in Georgia. Plant Dis. 81:1096.

11. Goris, J., Suzuki, K.-I., De Vos, P., Nakase, T., and Kersters, K. 1998. Evaluation of a microplate DNA-DNA hybridization method compared with the initial renaturation method. Can. J. Microbiol. 44:1148-1153.

12. Hauben, L., Moore, E. R. B., Vauterin, L., Steenackers, M., Mergaert, J., Verdonck, L., and Swings, J. 1998. Phylogenetic position of phytopathogens within the Enterobacteriaceae. System Appl. Microbiol. 21:384-397.

13. Mergaert, J., Verdonck, L., and Kersters, K. 1993. Transfer of Erwinia ananas (synonym, Erwinia uredovora) and Erwinia stewartii to the genus Pantoea emend. as Pantoea ananas (Serrano 1928) comb. nov. and Pantoea stewartii (Smith 1898) comb. nov., respectively, and description of Pantoea stewartii subsp. indologenes subsp. nov. Int. J. Syst. Bacteriol. 43:162-173.

14. Mergaert, J., Verdonck, L., Kersters, K.,
Swings, J., Bœufgras, J. M., and De Ley, J. 1984. Numerical taxonomy of Erwinia species using API systems. J. Gen. Microbiol. 130:1893-1910.

15. Mesbach, M., Premachandran, U., and Whitman, W. B. 1989. Precise measurement of the $\mathrm{G}+\mathrm{C}$ content of deoxyribonucleic acid by high-performance liquid chromatography. Int. J. Syst. Bacteriol. 39:159-167.

16. Neto, J. R., Robbs, C. F., and Yamashiro, T. 1987. A bacterial disease of guava (Psidium guajava) caused by Erwinia psidii sp. nov. Fitopatol. Bras. 12:345-350.

17. Pitcher, D. G., Saunders, N. A., and Owen, R. J. 1989. Rapid extraction of bacterial genomic DNA with guanidinium thiocyanate. Lett. Appl. Microbiol. 8:109-114.

18. Serrano, F. B. 1928. Bacterial fruitlet brownrot of pineapples in the Philippines. Philipp. J. Sci. 36:271-305.

19. Smith, H., Crous, P. W., Wingfield, M. J., Coutinho, T. A., and Wingfield, B. D. 2001. Botryosphaeria eucalyptorum sp. nov., a new species in the B. dothidea-complex on Eucalyptus in South Africa. Mycologia 93:277-285.

20. Smith, H., Kemp, G. H. J, and Wingfield, M. J. 1994. Canker and die-back of Eucalyptus in South Africa caused by Botryosphaeria dothidea. Plant Pathol. 43:1031-1034.
21. Thompson, J. D., Higgins, D. G., and Gibson, T. J. 1994. CLUSTAL W: improving the sensitivity of progressive multiple sequence alignment through sequence weighting, position-specific gap penalties and weight matrix choice. Nucleic Acids Res. 22:4673-4680.

22. Truman, R. 1974. Die-back of Eucalyptus citriodora caused by Xanthomonas eucalypti sp. n. Phytopathology 64:143-144.

23. Van Zyl, L. M. 1999. Factors associated with Coniothyrium canker of Eucalyptus in South Africa. Ph.D. thesis. University of the Orange Free State, Bloemfontein, South Africa.

24. Wells, J. M., Sheug, W. S., Ceponis, M. J., and Chen, T. A. 1987. Isolation and characterization of strains of Erwinia ananas from honeydew melons. Phytopathology 77:511514.

25. Wilmotte, A., van der Auwera, G., and De Wachter, R. 1993. Structure of the $16 \mathrm{~S}$ ribosomal DNA of the thermophilic cynobacterium Chlorogloeopsis HTF ("Mastigocladus laminosus HTF”) strain PCC7518, and phylogenetic analysis. FEBS Lett. 317:96-100.

26. Wingfield, M. J., Crous, P. W., and Coutinho, T. A. 1997. A serious canker disease of Eucalyptus in South Africa caused by a new species of Coniothyrium. Mycopathologia 136:139-145. 